\title{
Determination of volume of water reservoir by using tritium concentrations
}

\author{
E. Anovska ${ }^{1}$, Z. Jovcev, M. Arsov ${ }^{1}$, V. Popov ${ }^{1} \&$ T. Anovski ${ }^{2}$ \\ ${ }^{1}$ Wessex Institute of Technology, UK \\ ${ }^{2}$ Faculty of Technology and Metallurgy, \\ University of Sts Kiril \& Methodius, Republic of Macedonia
}

\begin{abstract}
Water supply, especially in urban areas, is one of the most important issues all over the world. Tritium ( $3 \mathrm{H}$ or $\mathrm{T})$ as a natural radioactive isotope of hydrogen with a half-life (T1/2) of 12.26 years has been accepted as an efficient tool in groundwater hydrology. By using an appropriate model, relevant hydro meteorological and isotope data, a computer program which implements an adequate recursive equation, the volume of the reservoir under the Galicica Mountain that recharges the St. Naum Spring as well as the Mean Residence Time (MRT) of the ground water has been determined and the respective values are $\mathrm{V}=3.7 \times 10^{9} \mathrm{~m}^{3}$ and $\mathrm{MRT}=6$ years.
\end{abstract}

Keywords: volume of water reservoir, mean residence time, tritium concentration.

\section{Introduction}

Prespa and Ohrid lakes region represents the biggest water system in the Balkans. The geological and hydro-geological characteristics of the region make this system unique and of great importance. Located on the South-Western part of the Republic of Macedonia, at an elevation of $695 \mathrm{~m}$ a.s.l. (see Figure 1), and surface of $348 \mathrm{~km}^{2}$, Ohrid Lake is registered by UNESCO as a world heritage site. It has been a subject of interest of numerous scientists of various profiles.

The neighboring Prespa Lake with surface of $253.6 \mathrm{~km}^{2}$ located at $847 \mathrm{~m}$ a.s.l, (see Figure 1), has been investigated by many scientists. Cvijic [1] by observing Prespa Lake at the beginning of the $20^{\text {th }}$ century, postulated that the water from this lake, having no surface outflow, has to sink through Mount Galichica 
(mostly karst) recharging St. Naum, Tushemiste and other Springs located along the Southern shore of Lake Ohrid. The first experimental research of the Ohrid Prespa Hydro system carried out by application of environmental isotope techniques confirmed the hydrological relationship between the Prespa and Ohrid lakes [4]. Since then Prespa Lake gained in its importance and attracted many other investigators, all in order to discover more about this system.

Recent research programmes that included research teams from Greece, Albania and Republic of Macedonia (FYROM) have established that the water level in the Big Prespa Lake has been lowering and the connection with the Small Prespa Lake has been interrupted. By application of natural isotope distribution, the existence of hydrological link between Prespa Lake and a series of springs on the South-eastern part of the Ohrid Lake has been established [5].

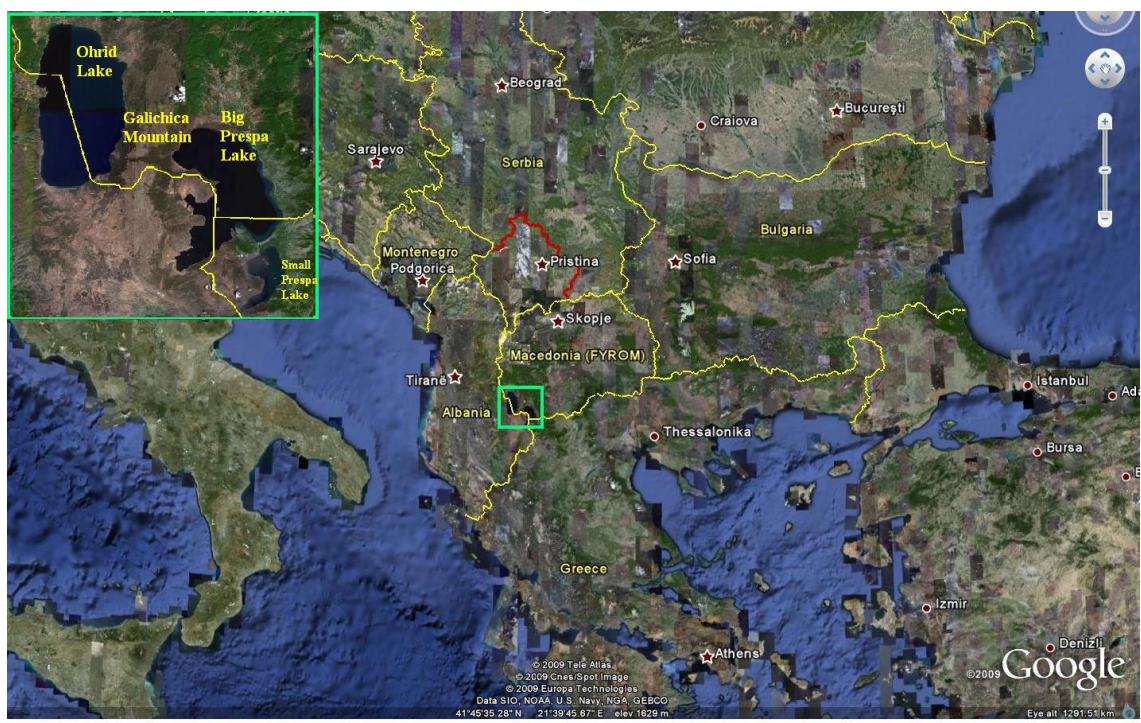

Figure 1: Ohrid-Prespa hydro system.

There were also investigations on: hydrogeology, quality of water, tracer hydrology and water balance, and charting and profiling of the bottom of the Lake $[6,7]$.

The decrease of the water level has not been explained yet, mainly because the water balance of the Lake could not be accurately performed. In order to solve this problem, an extensive research work (simultaneous observation of various hydro meteorological and hydro geological parameters, water balance, modeling of the infiltrated Praspa Lake water, etc) supported by NATO SfP, No. 981116 is under way [8].

In this paper, an approach of ground water modelling by application of tritium balancing is shown. Tritium $(3 \mathrm{H}$ or $\mathrm{T})$ is a natural radioactive isotope of the hydrogen with a half-life (T1/2) of 12.26 years. Hydrogen has the smallest mass and the highest difference in the masses of the isotopes that belong to the same 
element. Starting from its discovery it raised a great interest firstly among the physicists working on the theory of radioactive decay and later, up to present days, among the hydro geologists who use it as a natural tracer of water into its hydrological cycle. This tracer has been accepted as an efficient tool in groundwater hydrology in particular due to the fact, that after its formation into the upper atmosphere according to the following equation,

$$
n+{ }^{14} \mathrm{~N} \rightarrow{ }^{12} \mathrm{C}+{ }^{3} \mathrm{H}-4.5 \mathrm{MeV}
$$

oxidises to water, producing $\mathrm{HTO}$, which later with the precipitations reaches the ground and ground water. In the simplest way (Piston flow model), the concentration of the tritium in the precipitations after its infiltration into the ground starts to decrease following the law of radioactive decay,

$$
A=A_{0} * e^{-\lambda t}
$$

resulting in the possibility to determine the age of the ground water.

\section{Methodology}

According to the geological conditions and hydro geological characteristics of the Ohrid-Prespa region, observed tritium concentration into the local precipitations, Prespa Lake water and the spring water of St. Naum, a one cell model of two mixing components (precipitations over Galichica Mountain and infiltrated water through Galichica Mountain from Prespa Lake) has been proposed as illustrated in Figure 2.

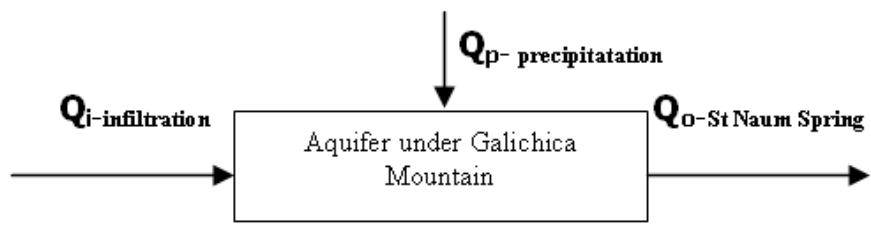

Figure 2: One Cell model including mixing of two components (precipitation, infiltration).

By analyzing the water balance in the hydrological system it was determined that $8.7 \mathrm{~m}^{3} / \mathrm{s}$ into the St. Naum, Tushemiste and other springs on the SouthEastern Coast of the Ohrid Lake are result of infiltration of water from the Prespa Lake. This was established by using nuclear related techniques [4, 9], i.e., stable isotopes ${ }^{2} \mathrm{H}$ and ${ }^{18} \mathrm{O}$. The study determined the following ratios of the water infiltrated from the Prespa Lake and from precipitations:

St. Naum Spring, $40 \%$ of the spring waters origins from the underground water from Prespa Lake and $60 \%$ from precipitation Tushemiste Spring, $55 \%$ of the spring waters origins from the underground water from Prespa Lake and $45 \%$ from precipitation 
- $\quad$ Other Springs, the possible ratio of the other unknown ground and underground springs was taken to be $45 \%$ from the Prespa Lake and $55 \%$ from precipitation

- $\quad$ Having established the above proportions it can be calculated that the precipitation over the Galichica Mountain is $10.9 \mathrm{~m}^{3} / \mathrm{s}$.

Taking into account the defined ratios it can be concluded that $19.6 \mathrm{~m}^{3} / \mathrm{s}$ is infiltrated through the Galichica Mountain into the Ohrid Lake. The aim of this study is to establish the size of the reservoir in the mountain and to determine the MRT.

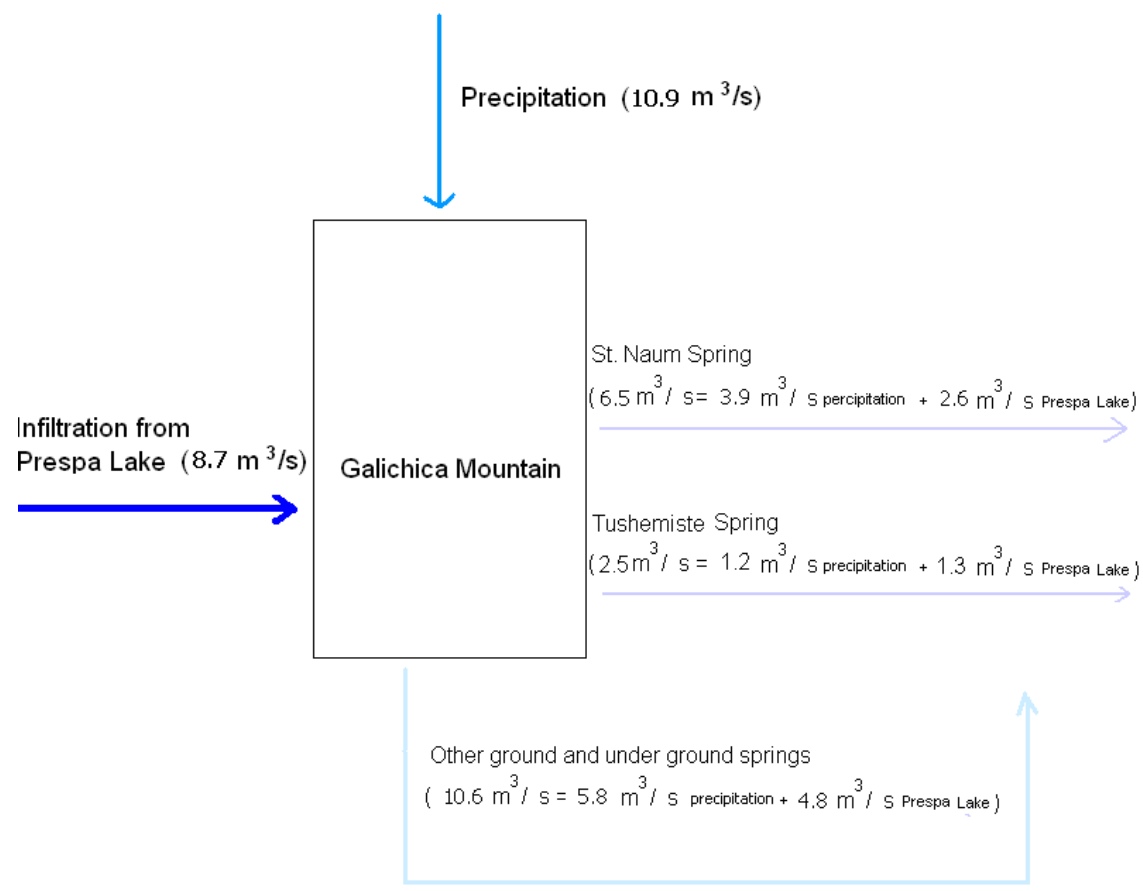

Figure 3: Ratio of the infiltration and precipitation.

By using the above mentioned model and a computer code solving the following recursive equation, the volume of the reservoir under the Galichica Mountain that recharge the St. Naum Spring as well as the mean residence time of the ground water have been determined:

$$
S_{n}=\left(S_{n-1}+B R F * C B R F-B O F * C B O F\right) * \alpha
$$

where:

$S_{n-1}$ - the calculated tritium concentration in the St. Naum Spring Waters, for the first year of observation, [TU], 
$\boldsymbol{S}_{\boldsymbol{0}}$ - initial tritium concentration, [TU],

$\boldsymbol{B R} \boldsymbol{F}$ - Boundary Recharge Fraction (precipitation and ground water),

$\boldsymbol{C B R F}$ - Concentration of Boundary Recharge Fraction, this value comes from measured or estimated TU in the precipitation over Republic of Macedonia for the corresponding year of observation. When ground water is considered this value is multiplied by the enrichment value due to evaporation of Prespa Lake,

$\boldsymbol{B} \boldsymbol{R} \boldsymbol{F}^{*} \boldsymbol{C B R F}$ - this product gives the boundary input mass within the cell,

BOF - Boundary Outlet Fraction (precipitation and ground water), equals BRFprecipitation + BRFground water,

CBOF - Concentration Boundary Outlet Fraction, for the first year of observation is So, [TU],

$\boldsymbol{B O F} * \boldsymbol{C B O F}$ - this product gives the boundary outlet mass leaving the cell,

$\boldsymbol{a}$ - radioactive decay constant.

\section{Computer simulation}

The computer program StNaumSim as shown in Figure 4 and Figure 5 gives the possibility to simulate the amount of tritium given in TU (Tritium Unit) in the St. Naum spring by changing the mean residence time and the enrichment of tritium content due to evaporation of the Prespa Lake.

By comparing the simulated results and the measured ones the mean residence time can be determined. The results that are given can be either printed or saved to a file.

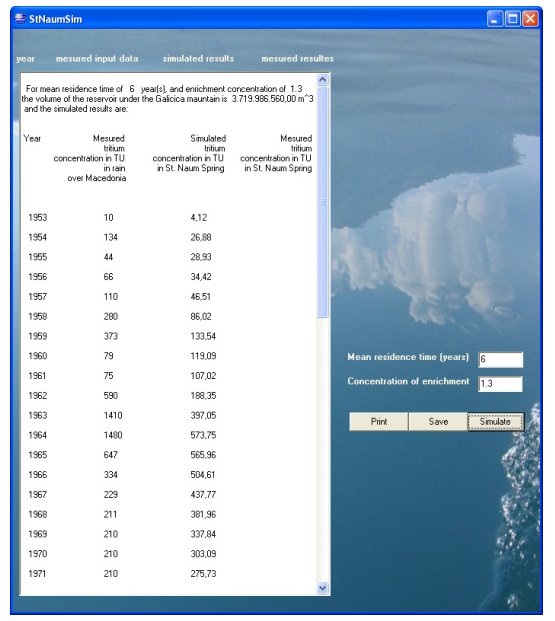

Figure 4: Computer program scrolled up.

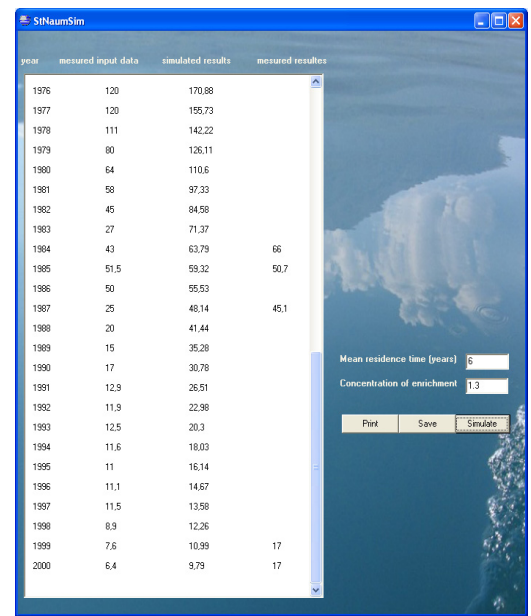

Figure 5: Computer program scrolled down. 


\section{Results and discussion}

After comparing the results for the different mean residence time and concentration of enrichment, it has been confirmed that by taking into account 6 years for mean residence time and 1.3 for the enrichment factor due to the evaporation within the Lake, the measured and the simulated results differ with minor acceptable deviations.

Taking into account the value of 6 years as a mean residence time, the discharge of series of springs on the South-Eastern Coast line of the Ohrid Lake as well as many relevant hydro meteorological and isotope data, the value of the volume of the ground water reservoir under the Galichica Mountain have been determined to be $3.7 \times 10^{9} \mathrm{~m}^{3}$.

\section{Conclusion}

On the basis of the performed study of the Prespa/Ohrid Hydro system, the following conclusions have been obtained:

1. Although the tritium content into the precipitation is approaching the natural level 4-6 TU it still can be used as an efficient tool in hydrological investigations.

2. As a mean residence time (MRT) for the water reaching the underground reservoir and suppling the St. Naum and other Springs located at the SouthEastern Coast of the Ohrid Lake a value of MRT $=6$ years has been calculated.

3. Taking into account the value of the MRT $=6$ years and other relevant hydrological parameters and isotope data (spring discharge, participation of Prespa Lake water into the water of the observed Springs), for the volume of the underground reservoir (under the Galichica Mountain) a value of cca $3.7 \times 10^{9}$ $\mathrm{m}^{3}$ has been estimated.

\section{Acknowledgement}

This work is supported by the NATO Science for Peace and Security programme (Project No. SfP 981116).

\section{References}

[1] Cvijic, J., 'Fundamentals of Geography and Geology of Macedonia and Serbia', Special edition VIII, Belgrade, Serbia, 1906.

[2] Kirkov, P., Kacurkov, D. Tolev, M. Anovski, T. "Determination the origin of water in Springs by application of natural and artificial isotopes", IAEA SM 182/23, 1984.

[3] Anovski, T. Andonovski, B. "Contribution to the Study of Dynamics in Karstic Springs”, IAHS Publication No.161, 1986. 
[4] Anovski T. et al. "A Study on the origin of the water of the St. Naum Springs, Lake Ohrid, A Journal of Experimental and theoretical physics", 1980.

[5] Anovski T. et al. "Study on Prespa Lake by application of nuclear and related techniques", IAEA / RER-8-008, 2002.

[6] Amataj, S. Anovski T. et al."Tracer method used to verify the hypothesis for hydrological relationship between Prespa and Ohrid Lake ", ENVIRON. GEOL. 2006.

[7] Anovski T. et al. Progress in Water Balance of the Prespa Lake, III Congress of Ecologists of Macedonia with international participation, Struga, 6-9 October, 2007.

[8] Popov,V., Anovski, T., Gospavic. R., Sustainable management of Prespa Lake. The Art of Resisting Extreme Natural Forces. Engineering Sciences Vol. 58, ISBN 978-184564-086-6,71-79, 2007.

[9] Eftimi, R., Zoto, J., 'Isotope study of the concentration of Ohrid and Prespa Lakes', International Symposium “Towards integrated Conservation and Sustainable development of Transboundary Macro and Micro Prespa Lakes", Korcha, Albania, 1997, pp 32-37. 